\title{
Reproductive Toxicity Evaluation of Pestban Insecticide Exposure in Male and Female Rats
}

\author{
Ashraf M. Morgan ${ }^{1}$ and A. M. Abd El-Aty ${ }^{2,3}$ \\ ${ }^{1}$ Department of Toxicology and Forensic Medicine; Faculty of Veterinary Medicine, \\ Cairo University, 12211-Giza, Egypt \\ ${ }^{2}$ Department of Veterinary Pharmacology and Toxicology, College of Veterinary Medicine, \\ Konkuk University, 1 Hwayang-dong, Kwangjin-gu, Seoul 143-701, Korea \\ ${ }^{3}$ Department of Pharmacology, Faculty of Veterinary Medicine, Cairo University, 12211-Giza, Egypt
}

Received February 29, 2008; Revised May 2, 2008; Accepted May 2, 2008

\begin{abstract}
Sexually mature male and female rats were orally intubated with the organophosphorus insecticide, Pestban at a daily dosage of 7.45 or $3.72 \mathrm{mg} / \mathrm{kg}$ bwt, equivalent to $1 / 20$ and $1 / 40 \mathrm{LD}_{50}$, respectively. Male rats were exposed for 70 days, while the female rats were exposed for 14 days, premating, during mating and throughout the whole length of gestation and lactation periods till weaning. The results showed depressed acetylcholinesterase (AChE) activity in the brain of parents, fetuses and their placentae in a dose-dependent manner. The fertility was significantly reduced with increasing the dose in both treated groups, with more pronounced suppressive effects in the male treated group. The number of implantation sites and viable fetuses were significantly reduced in pregnant females of both treated groups. However, the number of resorptions, dead fetuses, and pre-and postimplantation losses were significantly increased. The incidence of resorptions was more pronounced in treated female compared to male group and was dose dependant. The behavioral responses as well as fetal survival and viability indices were altered in both treated groups during the lactation period. The incidence of these effects was more pronounced in the treated female group and occurred in a dose-related manner. The recorded morphological, visceral, and skeletal anomalies were significantly increased with increasing the dose in fetuses of both treated groups, with more pronounced effects on fetuses of treated females. In conclusion, the exposure of adult male and female rats to Pestban would cause adverse effects on fertility and reproduction.
\end{abstract}

Key words: Pestban, Chlorpyrifos, Fertility, Reproduction, Rats.

\section{INTRODUCTION}

Pesticides occupy a unique position among the many hazardous chemicals that man and animals encounter daily. Nowadays, insecticides especially organophosphorus insecticides (OPI) are extensively used in agriculture and in residential settings for combating insects (Whyatt et al., 2002). They are powerful inhibitors of carboxylic ester hydrolases, including acetylcholinesterase (AChE) and butyrylcholinesterase (Karalliedde et al., 2001). Moreover, prolonged exposure to these contaminants causes chronic neurologic syndrome, terato-

Correspondence to: A.M. Abd El-Aty, Department of Veterinary Pharmacology and Toxicology, College of Veterinary Medicine, Konkuk University, 1 Hwayang-dong, Kwangjin-gu, Seoul 143-701, Korea

E-mail: abdelaty44@hotmail.com genicity and male reproductive failure (Nafstad et al., 1983). Some OPI are known to impair fertility, cause testicular degeneration, deteriorate semen quality in rodents (Bansal et al., 1994) and bulls (Hass et al., 1983), exert estrogenic (Garey and Wolff, 1998; Andersen et al., 2002) and antiandrogenic (Tomura et al., 2001; Kitamura et al., 2003; Kojima et al., 2004) activities.

Exposure of rodent dams during pregnancy to certain OPI, such as diazinon (Lozano et al., 1989), phosphamidon (Soni and Bhatngar, 1989), dimethoate (Weber, 1990), chlorpyrifos (Chanda et al., 1995), quinalphos (Srivastava et al., 1992) and dimethoate (Srivastava and Raizada, 1996), has been associated with decrements in fetal growth, embryo/fetotoxicity and teratogenicity in some studies. Other studies on the same pesticides (Institoris et al., 1995) and other organophos- 
phates (Clemens et al., 1990; Institoris et al., 1995) have shown no association with fetal growth. Scanty animal studies have examined the relationship of length of gestation and organophosphate pesticide exposure. The few studies that have examined the association of prenatal pesticide exposure and fetal growth or gestational duration in humans have also shown conflicting results (Willis et al., 1993; Kristensen et al., 1997; Dabrowski et al., 2003).

Pestban, the tested insecticide in our study is a product name for an organophosphorus insecticide containing $48 \%$ chlorpyrifos (CPF), an active ingredient widely used in agricultural practice. It is a cholinesterase inhibitor used against plants and household pests as well as to control cattle and sheep ectoparasites (Worthing and Walker, 1994). There is a growing body of literature suggesting a role for both acetylcholinesterase and butyrylcholinesterase in development (Layer and Willobold, 1995; Small et al., 1996). Although CPF is a suspected developmental neurotoxicant (Dam et al., 1998; Crumpton et al., 2000; Raines et al., 2001) and exerts some of its effects through cholinesterase inhibition, recent studies showed transplacental disposition and teratogenic effects of CPF when female rats were exposed to high CPF levels (Farag et al., 2003; Akhtar et al., 2006). Moreover, CPF is known to cross the placental barrier and inhibit AChE in the fetuses especially in the fetal brain (Dam et al., 1998; Akhtar et al., 2006). These toxicity evaluations have been performed only within limited exposure period of gestation on CPF and were not on Pestban itself. Comprehensive data assessing Pestban effects on length of gestation, reproductive performance and fertility of both males and females has been very limited. Moreover, data addressing its possible adverse effects on lactation exposure are lacking. Therefore, the present study aimed to investigate its effects on the reproductive performance and fertility of both male and female rats, as well as on the incidence of teratogenicity and behavioral effects on the offspring.

\section{MATERIALS AND METHODS}

Chemicals. Pestban (O, O-diethyl-O-3, 5,6-trichloro2-pyridyl-phosphorothioate), CAS RN/ $2921-88-2$, Developmental code Dowco 179 is one of the commonly used organophosphorus insecticides in Egypt. The commercial formulation used in this study was provided by Agrochem Co. (Alexandria, Egypt). It was available as $48 \%$ liquid solution. $\left[{ }^{3} \mathrm{H}\right]$ acetylcholine iodide (specific activity $55.2 \mathrm{mCi} / \mathrm{mmol}$ ) was purchased from New England Nuclear (Boston, MA). All other used chemicals were of highest purity and analytical grade.

Animals. Fifty mature males and one hundred mature female Sprague-Dawley rats, 3 months of age and weighing from 180 to $200 \mathrm{~g}$, were used in this study. They were kept under good ventilation and standard hygienic conditions with 12 hour darkness schedule in cages containing four to five animals. Food and water are supplied ad libitum.

Experimental design and administration of the tested chemical. The animals were divided into three main groups. The first group consisted of 10 males and twenty females, was given distilled water orally and kept as a control. However, the second and third treated groups were consisted of 20 males and 40 females per group. They were given Pestban by oral intubation at 7.45 and $3.72 \mathrm{mg} / \mathrm{kg}$ bwt, equivalent to $1 / 20$ and $1 / 40$ $\mathrm{LD}_{50}$, respectively (Worthing and Walker, 1994). Doses were adjusted daily based on weight changes. Male rats were exposed for 70 days; half of the females were dosed for 61 days [14 days premating, during mating and throughout the whole length of gestation, and lactation periods till weaning ( 21 day after birth)] and the other half exposed only for 40 days (till $20^{\text {th }}$ day of gestation) (Manson and Kang, 1989).

Examination of male fertility. Fertility was estimated in 10 adult exposed males/dose and in another 10 control male counterparts according to the method of Manson and Kang (1989). At the end of the exposure period, each male was placed in a separate cage with two virgin untreated females of the same strain. They were left together for 5 days, during this period, one estrus cycle should be elapsed (Fox and Laird, 1970). The presence of sperms in the vaginal smear was designed as zero day of gestation (Kanojia et al., 1996). The untreated females, which have been paired with treated males, were investigated to evaluate the effects of Pestban exposure on fertility. Half of these untreated females were sacrificed with their fetuses at $20^{\text {th }}$ day of gestation, while the other half was sacrificed with their pups at day 21 of lactation to record the fertility endpoints. The most indicative fertility endpoints according to Manson and Kang (1989) were measured and recorded as following; mating and fertility indices, number of dams showed delayed birth date, signs of dystocia, number of corpora lutea, implantation sites, resorped, dead and live fetuses, pre-and postimplantation losses, dam's body weight at the end of gestation period, gravid uterine and placental weights, fetal body weight (at birth, and at days 4, 7, 14, and 21 after 
birth), and fetal survival and viability indices during lactation period.

The Pestban exposed males were removed after the mating period and killed by cervical dislocation under light ether anesthesia and the following measurements were recorded: body weight, weights and histopathology of testes, epididymis, prostate and seminal vesicles.

The control male group was mated with 20 untreated females and the endpoints of fertility were recorded in the same manner as aforementioned above in treated male group. In addition, brain tissue samples were taken from the control, treated males, and their offsprings for AChE assay.

Examination of female fertility. Fertility was estimated in 20 adult exposed female rats/ dose and in another 20 control female counterparts according to the method of Manson and Kang (1989). After 14 days of Pestban exposure, each two females were placed in an individual cage with one adult untreated male of proven fertility and of the same strain. They were left together for 5 days, during this period one estrus cycle should be elapsed (Fox and Laird, 1970). The control female counterparts were also caged with untreated males.

The control and Pestban-exposed females were examined for estrus cycle regularity during the premating period (Manson and Kang, 1989). These females were sacrificed (half of them at day 20 of gestation and the other half at day 21 of lactation) with their offspring and the fertility endpoints were recorded in the same manner as previously mentioned in male fertility study. Brain tissue samples of both dams and their offsprings were also taken for AChE assay.

Determination of acetylcholinesterase activity. All frozen (at $-70^{\circ} \mathrm{C}$ ) parental (males and females) and fetal brains and placentae were thawed at room temperature and suspended in $50 \mathrm{mM}$ Tris- $\mathrm{HCl}$ buffer, $\mathrm{pH} 7.4\left(25^{\circ} \mathrm{C}\right)$ containing $\mathrm{NaCl}, 120 \mathrm{mM} ; \mathrm{KCl}, 5 \mathrm{mM} ; \mathrm{CaCl}_{2}, 2 \mathrm{mM}$; and $\mathrm{MgCl}_{2}, 1 \mathrm{mM}$. Tissues were homogenized $(1: 30$, w/v) on ice with a Polytron PT 3000 homogenizer at $28,000 \mathrm{rpm}$ for $20 \mathrm{~s}$. Tissue homogenates were assayed for ChE activity. The enzyme activity was measured by the radiometric method, using a final concentration of $1 \mathrm{mM}[3 \mathrm{H}]$ acetylcholine iodide (Johnson and Russell, 1975). Each reaction vial $(0.1 \mathrm{ml}$ final volume) contained $0.1 \%$ Triton $\mathrm{X}-100$ to aid tissue disruption. Preliminary experiments delineated conditions of both incubation time and tissue concentration necessary for linear rates of substrate hydrolysis. Acetylcholinesterase activity was determined by measuring the rate of hydrolysis of acetylcholine iodide $\left(3 \times 10^{-3} \mathrm{M}\right)$ in buffer
(pH 8). Substrate was incubated with brain $(2.5 \mathrm{mg}$ wet tissue) in a total volume of $3.2 \mathrm{ml}$. The absorbance $(412 \mathrm{~nm})$ was recorded using a Spectronic 21D Spectrophotometer. Cholinesterase activities were expressed as $\mathrm{nmol} / \mathrm{min} / \mathrm{mg}$ protein. Protein content of all samples was estimated by the method of Lowry et al. (1951) using BSA (bovine serum albumin) as a standard.

Examination of the obtained fetuses. All the obtained pups (At $20^{\text {th }}$ day of gestation and at $21^{\text {st }}$ day of lactation) from all groups were examined for presence of any gross malformation and behavioral defects (Manson and Kang, 1989).

One third of the obtained fetuses were preserved in Bouin's solution and examined for presence of any visceral anomalies using the Wilson free hand sectioning technique (Wilson, 1973). The remaining two thirds of the fetuses were preserved in $95 \%$ ethanol and examined for presence of any skeletal anomalies according to the method of Manson and Kang (1989).

Statistical analysis. Data presented as percentage were analyzed using Chi-Square test; however, other data were analyzed using one-way ANOVA test. The differences in the data were considered statistically significant at $p<0.05$ (Norusis, 1994).

\section{RESULTS}

Clinical signs of toxicity and acetylcholinesterase activity. There were no deaths observed during the experimental period. Neither clinical signs nor notable changes in behavior were observed in control or in both treated males and females at the dose of $1 / 40 L_{50}$ (3.72 mg/kg bwt). However, signs of cholinergic toxicity including tremors and salivation were noted in $60 \%$ of treated males and in $70 \%$ of treated females at the dose rate of $1 / 20 \mathrm{LD}_{50}(7.45 \mathrm{mg} / \mathrm{kg}$ bwt). Parental (male and female) and offspring's brain (at $20^{\text {th }}$ day of gestation and after weaning) and placental cholinesterase activities were significantly decreased in a dose related manner with more marked reduction in the treated female groups (Table 1).

\section{Effects of Pestban on fertility of male and female} rats. Table 2 demonstrates that the fertility was significantly reduced in untreated female group impregnated with treated males and in treated female group impregnated with untreated males. The estrus cycle regularity was disturbed in the Pestban-exposed females. The mating and fertility indices were significantly reduced in both treated male and female groups compared with 
Table 1. Effect of Pestban exposure on brain and placental AChE ( $\mathrm{nmol} / \mathrm{mg}$ protein/min) of adult male and female rats and their offsprings

\begin{tabular}{|c|c|c|c|c|c|}
\hline \multirow[b]{2}{*}{ Parameters } & \multirow{2}{*}{$\begin{array}{l}\text { Control group } \\
\text { (10 male } \\
+20 \text { female })\end{array}$} & \multicolumn{2}{|c|}{$\begin{array}{l}\text { Treated male groups ( } 10 \text { treated male } \\
+20 \text { untreated female/dose) }\end{array}$} & \multicolumn{2}{|c|}{$\begin{array}{l}\text { Treated female groups (10 untreated } \\
\text { male }+20 \text { treated female/dose) }\end{array}$} \\
\hline & & At $7.45 \mathrm{mg} / \mathrm{kg}$ & At $3.72 \mathrm{mg} / \mathrm{kg}$ & At $7.45 \mathrm{mg} / \mathrm{kg}$ & At $3.72 \mathrm{mg} / \mathrm{kg}$ \\
\hline Parental brain AchE $^{a}$ & $\begin{array}{c}28.41 \pm 6.70 \\
\text { (male \& female) }\end{array}$ & $\begin{array}{l}19.31 \pm 4.14^{\mathrm{b}} \\
\text { (male) }\end{array}$ & $\begin{array}{l}24.15 \pm 6.41 \\
\text { (male) }\end{array}$ & $\begin{array}{l}16.83 \pm 3.98^{b} \\
\quad(\text { female })\end{array}$ & $\begin{array}{l}21.90 \pm 6.57^{b} \\
(\text { female })\end{array}$ \\
\hline $\begin{array}{l}\text { Fetal (At } 20^{\text {th }} \text { day of gestation) } \\
\text { brain AchE }\end{array}$ & $30.11 \pm 8.40$ & $27.34 \pm 6.86$ & $29.45 \pm 6.82$ & $21.55 \pm 6.01^{\mathrm{b}, \mathrm{c}}$ & $22.14 \pm 6.48^{\mathrm{b}, \mathrm{d}}$ \\
\hline Weaned offsprings brain $A_{c h}{ }^{a}$ & $34.66 \pm 9.64$ & $31.77 \pm 9.76$ & $32.69 \pm 9.80$ & $23.56 \pm 6.83^{b, c}$ & $30.69 \pm 9.13$ \\
\hline Placental AchE ${ }^{a}$ & $23.13 \pm 6.67$ & $19.75 \pm 4.90$ & $21.29 \pm 5.85$ & $13.10 \pm 3.86^{b, c}$ & $16.44 \pm 4.55^{\mathrm{b}, \mathrm{d}}$ \\
\hline
\end{tabular}

Values are expressed as mean \pm SD.

bSignificant difference between control and Pestban-treated groups by one-way ANOVA test.

'Significant difference between Pestban-treated groups at $7.45 \mathrm{mg} / \mathrm{kg}$ bwt by one-way ANOVA test.

${ }^{\mathrm{d}}$ Significant difference between Pestban-treated groups at $3.72 \mathrm{mg} / \mathrm{kg}$ bwt by one- way ANOVA test.

Table 2. Effect of Pestban exposure on fertility and reproductive performance of male and female rats

\begin{tabular}{|c|c|c|c|c|c|c|}
\hline \multirow[t]{2}{*}{ Groups } & \multirow[b]{2}{*}{ Parameters } & \multirow{2}{*}{$\begin{array}{l}\text { Control group } \\
\qquad(10 \text { male } \\
+20 \text { female })\end{array}$} & \multicolumn{2}{|c|}{$\begin{array}{c}\text { Treated male groups } \\
(10 \text { treated male } \\
+20 \text { untreated female/dose })\end{array}$} & \multicolumn{2}{|c|}{$\begin{array}{c}\text { Treated female groups } \\
(10 \text { untreated male } \\
+20 \text { treated female/dose })\end{array}$} \\
\hline & & & At $7.45 \mathrm{mg} / \mathrm{kg}$ & At $3.72 \mathrm{mg} / \mathrm{kg}$ & At $7.45 \mathrm{mg} / \mathrm{kg}$ & At $3.72 \mathrm{mg} / \mathrm{kg}$ \\
\hline \multicolumn{2}{|c|}{ No. of females showing regular estrus cycle } & 20 & 20 & 20 & 14 & 16 \\
\hline \multicolumn{2}{|c|}{ No. of females with confirmed matings } & 20 & 13 & 15 & 12 & 15 \\
\hline \multicolumn{2}{|c|}{ No. of pregnant females } & 18 & 6 & 8 & 10 & 13 \\
\hline \multicolumn{2}{|c|}{ Mating index (\%) } & 100 & $65^{\mathrm{bc}}$ & $75^{\text {bd }}$ & $85.71^{\mathrm{b}}$ & 93.75 \\
\hline \multicolumn{2}{|c|}{ Fertility index (\%) } & 95 & $46.15^{\mathrm{bc}}$ & $53.33^{\text {bd }}$ & $83.33^{\mathrm{b}}$ & $86.66^{\mathrm{b}}$ \\
\hline \multicolumn{2}{|c|}{$\begin{array}{l}\text { No. of dams showed preterm labor } \\
\text { (shortened birth date) }\end{array}$} & 0 & 4 & 2 & 6 & 4 \\
\hline \multicolumn{2}{|c|}{ No. of dams showed signs of dystocia } & 0 & 2 & 1 & 3 & 2 \\
\hline \multicolumn{2}{|c|}{ Total No. of corpora lutea } & 203 & 54 & 56 & 74 & 96 \\
\hline \multicolumn{2}{|c|}{ Total No. of implantations } & 200 & 38 & 55 & 65 & 92 \\
\hline \multicolumn{2}{|c|}{ No. of implants/dam ${ }^{a}$} & $10.51 \pm 1.46$ & $6.30 \pm 1.70^{b}$ & $7.30 \pm 1.58^{b}$ & $6.28 \pm 1.56^{b}$ & $6.64 \pm 1.78^{b}$ \\
\hline \multicolumn{2}{|c|}{ No. of resoptions/dam ${ }^{a}$} & 0 & $2.31 \pm 0.24^{b}$ & $1.12 \pm 0.19^{b}$ & $2.70 \pm 0.36^{\mathrm{bc}}$ & $1.83 \pm 0.56^{\mathrm{bd}}$ \\
\hline \multicolumn{2}{|c|}{ No. of dead fetuses/dam ${ }^{a}$} & $0.10 \pm 0.02$ & $1.16 \pm 0.19^{b}$ & $1.10 \pm 0.17^{b}$ & $1.19 \pm 0.31^{b}$ & $1.15 \pm 0.26^{b}$ \\
\hline \multicolumn{2}{|c|}{ No. of live fetuses/dam ${ }^{a}$} & $10.29 \pm 1.61$ & $3.92 \pm 0.93^{b}$ & $4.92 \pm 1.58^{\mathrm{b}}$ & $2.38 \pm 0.75^{\mathrm{bc}}$ & $3.66 \pm 0.98^{\mathrm{b}}$ \\
\hline \multicolumn{2}{|c|}{ Preimplantation loss (\%) } & $1.48 \pm 0.07$ & $29.63 \pm 5.14^{b c}$ & $1.78 \pm 0.17^{b}$ & $12.16 \pm 2.95^{\mathrm{b}}$ & $4.16 \pm 0.96^{\mathrm{bd}}$ \\
\hline \multicolumn{2}{|c|}{ Postimplantotion loss (\%) } & $4.50 \pm 0.80$ & $39.47 \pm 6.12^{\mathrm{b}}$ & $29.09 \pm 5.22^{b}$ & $63.07 \pm 10.37^{\mathrm{bc}}$ & $48.91 \pm 8.29^{\mathrm{bd}}$ \\
\hline \multicolumn{2}{|c|}{ Body weight/dam at termination $(\mathrm{g})^{\mathrm{a}}$} & $255.30 \pm 24.15$ & $225.63 \pm 27.94^{b}$ & $226.20 \pm 28.06^{b}$ & $220.50 \pm 28.79^{b}$ & $223.80 \pm 28.47^{b}$ \\
\hline \multicolumn{2}{|c|}{ Gravid uterine weight/dam $(\mathrm{g})^{a}$} & $66.40 \pm 7.02$ & $35.75 \pm 8.05^{\mathrm{b}}$ & $39.80 \pm 9.27^{b}$ & $29.15 \pm 3.56^{\text {bc }}$ & $32.35 \pm 3.95^{\mathrm{bd}}$ \\
\hline \multicolumn{2}{|c|}{ Placental weight/fetus $(g)^{a}$} & $0.48 \pm 0.06$ & $0.33 \pm 0.16^{b}$ & $0.41 \pm 0.15$ & $0.26 \pm 0.09^{b}$ & $0.28 \pm 0.12^{\mathrm{bd}}$ \\
\hline \multirow[t]{2}{*}{ Mean } & At birth & $5.53 \pm 0.47$ & $5.31 \pm 0.82$ & $5.40 \pm 0.37$ & $4.12 \pm 0.63^{b c}$ & $4.42 \pm 0.69^{\text {bd }}$ \\
\hline & At $4^{\text {th }}$ day pp & $8.02 \pm 1.73$ & $7.65 \pm 1.89$ & $7.68 \pm 1.90$ & $5.10 \pm 2.33^{b c}$ & $6.15 \pm 2.84^{b}$ \\
\hline \multirow{3}{*}{$\begin{array}{l}\text { Fetal } \\
\text { Weight } \\
(g)^{a}\end{array}$} & At $7^{\text {th }}$ day pp & $9.15 \pm 2.43$ & $8.11 \pm 3.03$ & $8.70 \pm 2.59$ & $5.55 \pm 2.46^{b c}$ & $6.65 \pm 1.76^{\mathrm{bd}}$ \\
\hline & At $14^{\text {th }}$ day $\mathrm{pp}$ & $12.18 \pm 2.84$ & $9.41 \pm 3.35^{b}$ & $10.26 \pm 2.93$ & $6.82 \pm 3.06^{b c}$ & $9.22 \pm 2.84^{\mathrm{b}}$ \\
\hline & At $21^{\text {st }}$ day $\mathrm{pp}$ & $23.25 \pm 4.93$ & $18.80 \pm 5.37^{b}$ & $20.02 \pm 6.16$ & $10.14 \pm 4.61^{\mathrm{bc}}$ & $12.14 \pm 6.16^{\mathrm{bd}}$ \\
\hline \multicolumn{2}{|c|}{ Live/birth index (\%) } & 100 & 95.83 & 100 & 91.66 & 97.91 \\
\hline \multicolumn{2}{|c|}{ Survival index $(\%)$} & 100 & 95.65 & 100 & 90.91 & 97.87 \\
\hline \multicolumn{2}{|c|}{ Viability index (\%) } & 99.53 & 91.30 & 97.43 & 81.82 & 95.74 \\
\hline
\end{tabular}

PP: Postpartum.

${ }^{a}$ Values are expressed as mean $\pm \mathrm{SD}$.

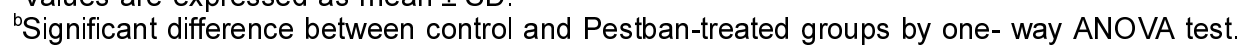

'Significant difference between Pestban-treated groups at $7.45 \mathrm{mg} / \mathrm{kg}$ bwt by one-way ANOVA test.

${ }^{\mathrm{d}}$ Significant difference between Pestban-treated groups at $3.72 \mathrm{mg} / \mathrm{kg}$ bwt by one-way ANOVA test.

the control group, with more suppression of these indices in the male treated group. These effects occurred in a dose-related manner.
No signs of dystocia or preterm labor (shortened birth date) detected in the control females. However at the highest dose level, $60 \%$ of the treated females impreg- 


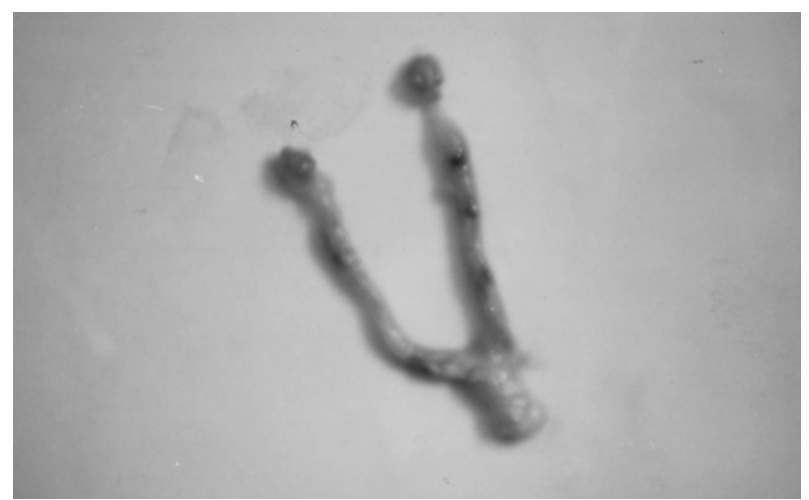

Fig. 1. Uterus of pregnant rat exposed to Pestban at $7.45 \mathrm{mg} / \mathrm{kg}$ bwt orally and impregnated with untreated males showing postimplantation death.

nated with untreated males showed preterm labor (shortened birth date) and $30 \%$ of them showed signs of dystocia compared to $66.66 \%$ and $33.33 \%$, respectively, for the untreated females impregnated with treated males. At the lowest dose, $30.77 \%$ of the treated females impregnated with untreated males showed preterm labor and $15.38 \%$ of them showed signs of dystocia compared to $25 \%$ and $12.5 \%$, respectively, for the untreated females impregnated with treated males.

The number of implantation sites and the number of viable fetuses were significantly reduced in pregnant females of both treated groups at the two dose levels compared with the control group. However, the number of resorptions (postimplantation deaths) (Fig. 1), dead fetuses and pre-and postimplantation losses were significantly increased in pregnant females of both treated groups. The incidence of resorptions was significantly increased with increasing the dose in treated female group impregnated with untreated males in comparison with untreated female group impregnated with treated males.

The placental, fetal, and gravid uterine weights were significantly decreased in both treated groups at the two dose levels compared with control group. The body weight of fetuses obtained from treated females impregnated with untreated males was significantly different (at birth and at the end of lactation period) from those obtained from untreated females impregnated with treated males.

During lactation, the pups behavioral responses (such as memory response), fetal survival and viability indices were decreased in both treated groups. The incidence of these effects was more pronounced in the treated female group impregnated with untreated males compared with untreated female group impregnated with treated males. At the highest dose, $50 \%$ of the off- springs obtained from the treated female group impregnated with untreated males showed mild cholinergic toxicity signs during lactation period such as tremors and salivation. These signs were not observed in the offsprings obtained from the untreated females impregnated with treated males. However at the lowest dose, no cholinergic toxicity signs appeared on the offsprings obtained from all treated groups.

Effects of Pestban on sex organ weights and histological structure of treated males. The body weight of male rats exposed to Pestban either at 7.45 or $3.72 \mathrm{mg} / \mathrm{kg}$ showed no significant alteration. However, the weights of testes, epididymis, prostate, and seminal vesicles were significantly reduced in a dosedependant manner compared with the control ones (Table 3).

Table 3. Body and sex organs weight (g) of adult male rats exposed to Pestban for 70 successive days

\begin{tabular}{|c|c|c|c|}
\hline \multirow{2}{*}{$\begin{array}{l}\text { Groups } \\
\text { Parameters }\end{array}$} & \multirow{2}{*}{$\begin{array}{l}\text { Control } \\
\text { males }\end{array}$} & \multicolumn{2}{|c|}{ Treated males } \\
\hline & & $\begin{array}{c}\text { At } \\
7.45 \mathrm{mg} / \mathrm{kg}\end{array}$ & $\begin{array}{c}\text { At } \\
3.72 \mathrm{mg} / \mathrm{kg}\end{array}$ \\
\hline Number of males & 10 & 10 & 10 \\
\hline Body weight ${ }^{\mathrm{a}}$ & $215 \pm 5.21$ & $197 \pm 5.05$ & $198 \pm 5.37$ \\
\hline Testes weight $^{\mathrm{a}}$ & $3.85 \pm 0.56$ & $2.70 \pm 1.04^{b}$ & $3.05 \pm 0.79^{b}$ \\
\hline Epididymis weight ${ }^{\mathrm{a}}$ & $0.64 \pm 0.15$ & $0.43 \pm 1.04^{b}$ & $0.54 \pm 0.22$ \\
\hline Prostate gland weight ${ }^{a}$ & $0.55 \pm 0.06$ & $0.41 \pm 0.09^{b c}$ & $0.49 \pm 0.12$ \\
\hline Seminal vesicles weight ${ }^{a}$ & $1.20 \pm 0.27$ & $0.87 \pm 0.22^{b}$ & $0.98 \pm 0.25$ \\
\hline
\end{tabular}

${ }^{a}$ Values are expressed as mean \pm SD.

bSignificant difference between control and Pestban-treated groups by one-way ANOVA test.

'Significant difference between the two Pestban-treated groups by one-way ANOVA test.

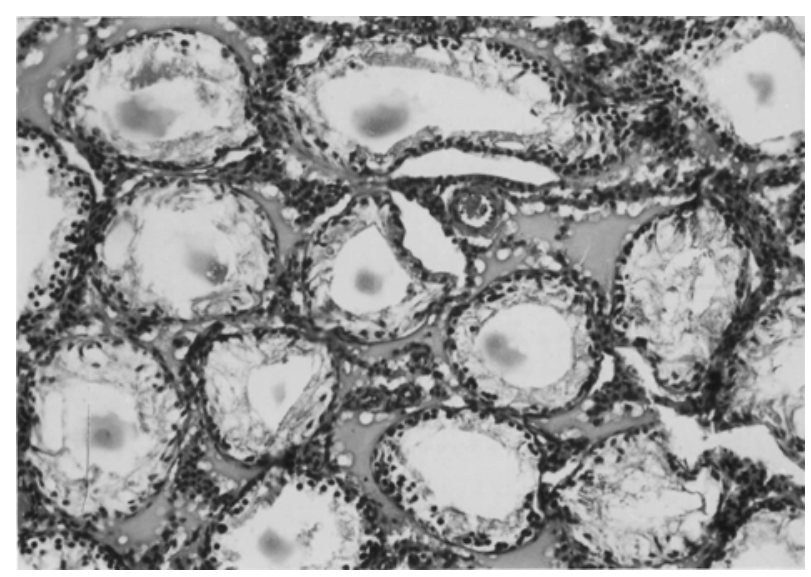

Fig. 2. Photomicrograph of the testis of rat exposed orally to $7.45 \mathrm{mg} / \mathrm{Kg}$ bwt Pestban daily for 60 days showing atrophied and degenerated seminiferous tubules with edema and hyperplasia of the interstitial Leydig cells $(H \& E, \times 40)$. 
Histopathological examination revealed different alterations in the sex organs of Pestiban-exposed animals including the testes, epididymis, prostate gland, and seminal vesicles. The histopathological lesions occurred in a dose-dependant manner. The seminiferous tubules were atrophied and showed degenerative changes in the germinal epithelium, desquamation of spermatogenic cells with appearance of Sertoli cells as predominating cells (Fig. 2) and hyperplasia of the interstitial Leydig cells (Fig. 3 ), at the high dose-exposed animals after 70 days exposure compared to control rat's testes. Moreover, vacuolation and degeneration of the seminiferous tubules (Fig. 4) were also seen at the low dose-exposed animals.

The epithelial lining of epididymal ducts showed mild hyperplasia with moderate inflammatory cells infiltration

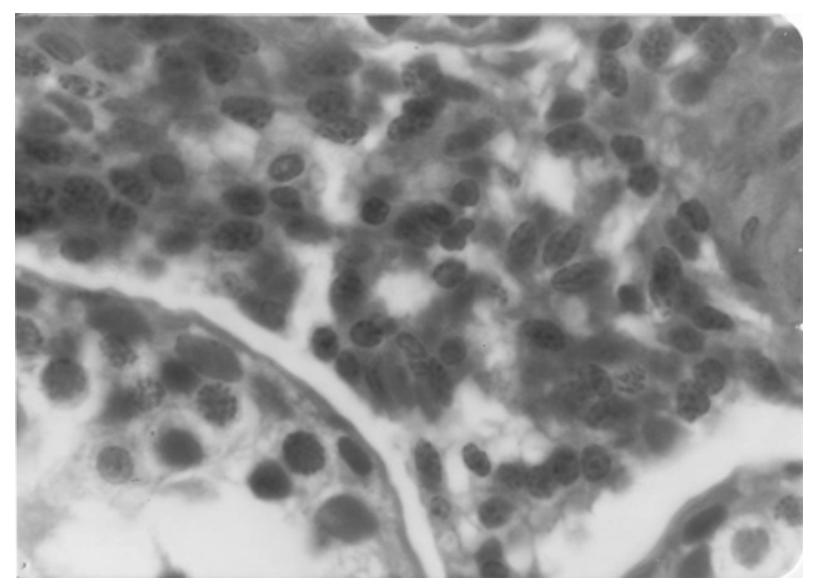

Fig. 3. A cross section in the testis of rat exposed orally to $7.45 \mathrm{mg} / \mathrm{kg}$ bwt Pestban daily for 60 days showing hypertrophy and hyperplasia of the interstitial Leydig cells ( $H \& E$, $\times$ 1000).

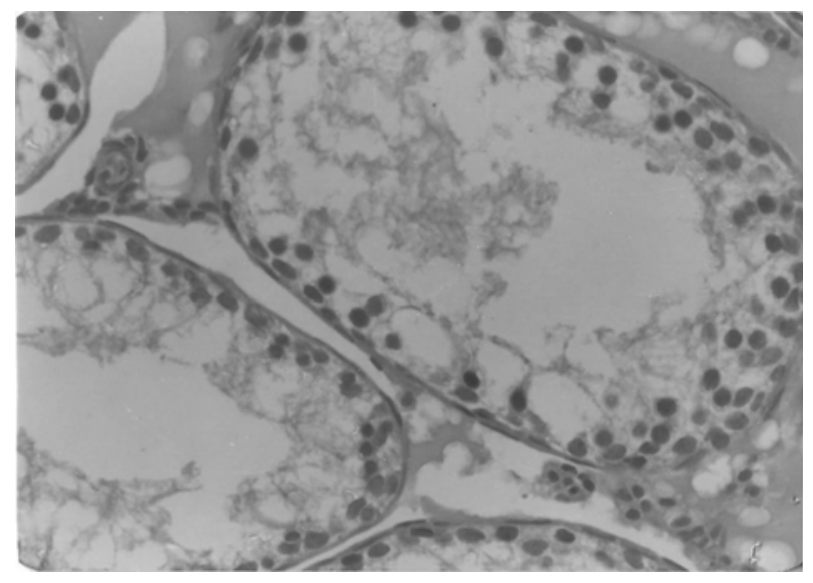

Fig. 4. A cross section in the testis of rat exposed orally to $3.72 \mathrm{mg} / \mathrm{kg}$ bwt Pestban daily for 60 days showing vacuolated and degenerated seminiferous tubules (H\& E, × 160).

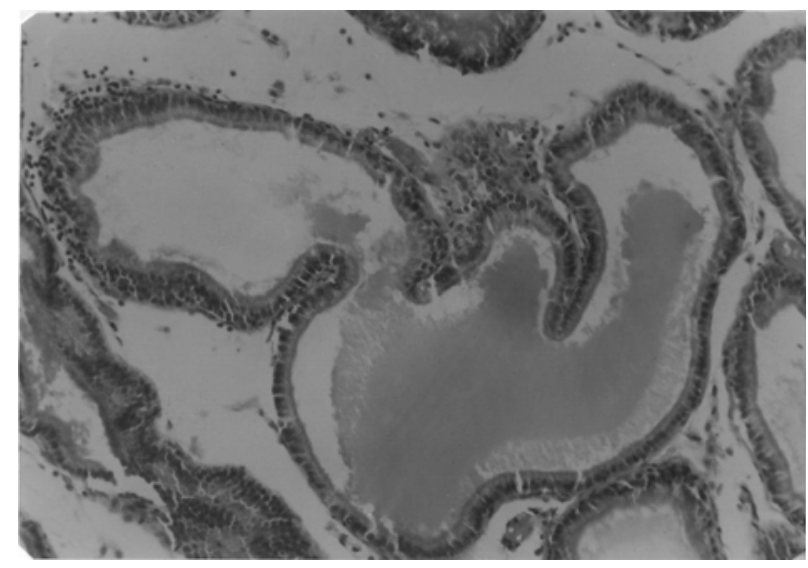

Fig. 5. A section in the epididymis of rat exposed orally to $7.45 \mathrm{mg} / \mathrm{kg}$ bwt Pestban daily for 60 days showing mild hyperplasia of the lining epithelium with moderate inflammatory cells infiltration and edema (H\& E, × 160).

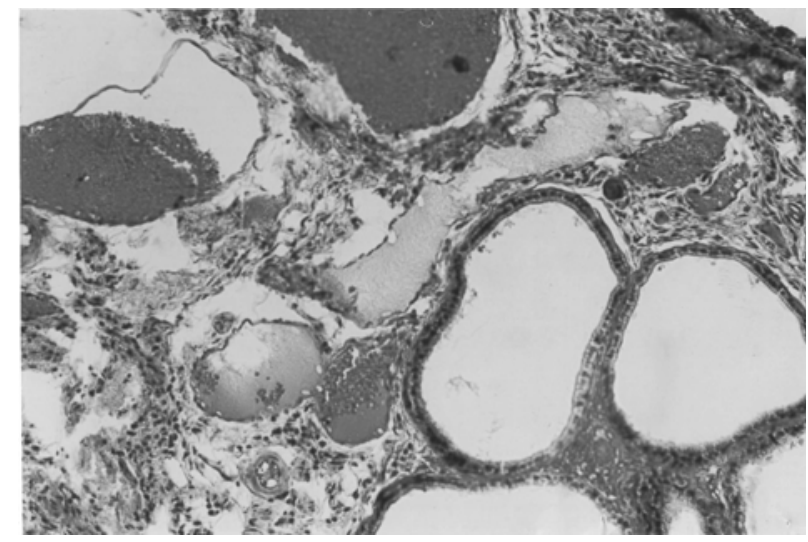

Fig. 6. A section in the prostate gland of rat exposed orally to $7.45 \mathrm{mg} / \mathrm{kg}$ bwt Pestban daily for 60 days showing massive numbers of dilated blood capillaries in the stromal tissue (Hemangioma) $(H \& E, \times 40)$.

and edema (Fig. 5) in the high dose-exposed animals. However, it showed only mild inflammatory cells infiltration in the low dose-treated group.

The prostate gland of the high dose-treated animals showed massive numbers of dilated blood capillaries in the stromal tissue (Hemangioma) (Fig. 6). On the other hand, it showed mononuclear inflammatory cells infiltration, edema, and dilated blood capillaries in the interacinar stroma with hyperplasia of its epithelial lining (Fig. 7) at the low dose of exposure. The seminal vesicle showed only mild inflammatory cells infiltration at the high dose-exposed animals.

Effects of Pestban on the incidence of developmental anomalies in the obtained fetuses. Gross examination of the fetuses of both treated groups 


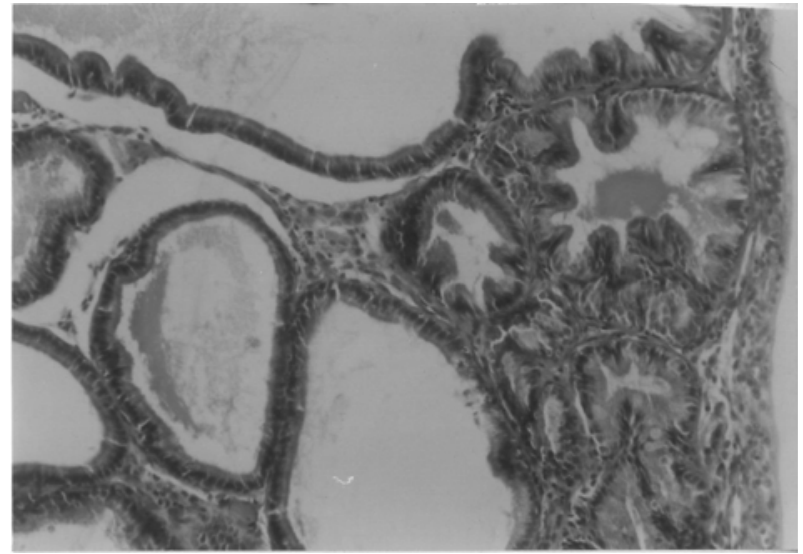

Fig. 7. Photomicrograph of the prostate gland of rat exposed orally to $3.72 \mathrm{mg} / \mathrm{kg}$ bwt Pestban daily for 60 days showing mononuclear inflammatory cells infiltration with oedema and dilated blood capillaries in the interacinar stroma and hyperplasia of the epithelial lining of the prostatic acini $(H \& E, \times 160)$.

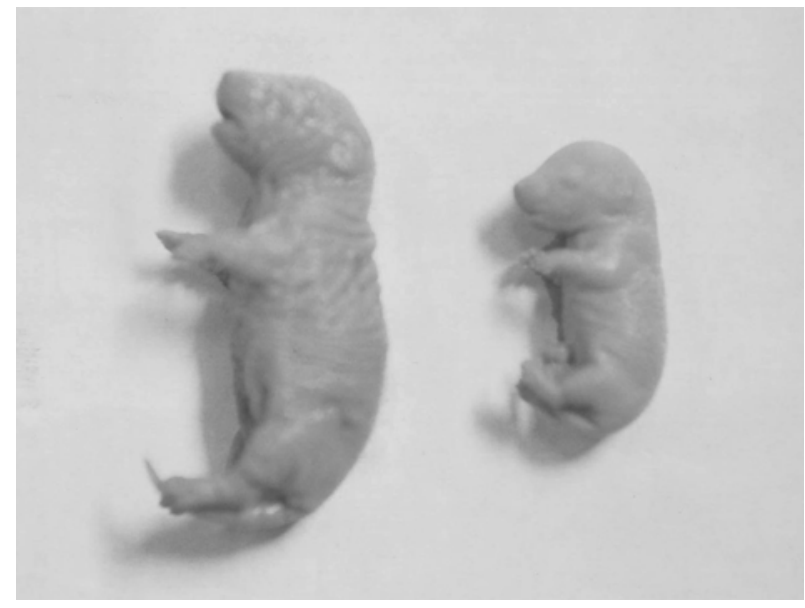

Fig. 8. A rat fetus obtained from an untreated dam impregnated with males exposed to Pestban at $3.72 \mathrm{mg} / \mathrm{kg}$ bwt orally for 60 days daily showing stunted growth (right) and a control fetus (left).

Table 4. Incidences of gross anomalies in the fetuses obtained from Pestban-exposed male and female rat groups

\begin{tabular}{|c|c|c|c|c|c|}
\hline \multirow{2}{*}{$\begin{array}{l}\text { Groups } \\
\text { Parameters }\end{array}$} & \multirow{2}{*}{$\begin{array}{l}\text { Fetuses of } \\
\text { control group }\end{array}$} & \multicolumn{2}{|c|}{ Fetuses of treated male group } & \multicolumn{2}{|c|}{ Fetuses of treated female groups } \\
\hline & & At $7.45 \mathrm{mg} / \mathrm{kg}$ & At $3.72 \mathrm{mg} / \mathrm{kg}$ & At $7.45 \mathrm{mg} / \mathrm{kg}$ & At $3.72 \mathrm{mg} / \mathrm{kg}$ \\
\hline Total fetuses examined & 191 & 23 & 39 & 22 & 47 \\
\hline Stunted growth ${ }^{\mathrm{a}}$ & 0 & $21.74^{b}$ & $10.26^{b}$ & $59.09^{\mathrm{bc}}$ & $29.79^{\text {bd }}$ \\
\hline Exencephaly ${ }^{a}$ & 0 & $17.23^{\mathrm{b}}$ & $7.69^{b}$ & $54.54^{\mathrm{bc}}$ & $27.66^{\text {bd }}$ \\
\hline Generalized edema $^{a}$ & 0 & $13.04^{\mathrm{b}}$ & $5.13^{b}$ & $45.45^{\mathrm{bc}}$ & $25.53^{\text {bd }}$ \\
\hline Micrognathia ${ }^{a}$ & 0 & $8.69^{b}$ & $5.13^{\mathrm{b}}$ & $40.90^{\mathrm{bc}}$ & $21.28^{\text {bd }}$ \\
\hline
\end{tabular}

${ }^{a}$ Values represent percentage of grossly deformed fetuses in relation to total number of fetuses examined.

bSignificant difference between control and Pestban-treated groups by Chi-Square test.

'Significant difference between Pestban-treated groups at $7.45 \mathrm{mg} / \mathrm{kg}$ bwt by Chi-Square test.

dSignificant difference between Pestban-treated groups at $3.72 \mathrm{mg} / \mathrm{kg}$ bwt by Chi-Square test.

Table 5. Incidences of visceral anomalies in the fetuses obtained from Pestban-exposed male and female rat groups

\begin{tabular}{|c|c|c|c|c|c|}
\hline \multirow{2}{*}{$\begin{array}{l}\text { Groups } \\
\text { Parameters }\end{array}$} & \multirow{2}{*}{$\begin{array}{l}\text { Fetuses of } \\
\text { control group }\end{array}$} & \multicolumn{2}{|c|}{ Fetuses of treated male group } & \multicolumn{2}{|c|}{ Fetuses of treated female groups } \\
\hline & & At $7.45 \mathrm{mg} / \mathrm{kg}$ & At $3.72 \mathrm{mg} / \mathrm{kg}$ & At $7.45 \mathrm{mg} / \mathrm{kg}$ & At $3.72 \mathrm{mg} / \mathrm{kg}$ \\
\hline Total fetuses examined & 64 & 8 & 13 & 8 & 16 \\
\hline Total fetuses with visceral anomalies & 2 & 3 & 2 & 7 & 9 \\
\hline Total fetuses with head anomalies & 0 & 2 & 1 & 5 & 5 \\
\hline -Dilated brain ventricles ${ }^{a}$ & 0 & $12.25^{\mathrm{b}}$ & $7.69^{b}$ & $62.50^{\mathrm{bc}}$ & $18.75^{\mathrm{bd}}$ \\
\hline -Dilated nares ${ }^{a}$ & 0 & $25.00^{\mathrm{b}}$ & $7.69^{b}$ & $50.00^{\mathrm{bc}}$ & $25.00^{\text {bd }}$ \\
\hline -Olfactory pulp hypoplasia ${ }^{a}$ & 0 & 0 & 0 & $25.00^{\mathrm{bc}}$ & $18.75^{\mathrm{bd}}$ \\
\hline -Cerebral hemisphere hypoplasia ${ }^{a}$ & 0 & $25.00^{b}$ & $7.69^{a}$ & $62.50^{\mathrm{bc}}$ & $25.00^{\text {bd }}$ \\
\hline -Micro-and anopthalmia ${ }^{a}$ & 0 & $12.25^{\mathrm{b}}$ & 0 & $50.00^{\mathrm{bc}}$ & $31.25^{\mathrm{bd}}$ \\
\hline Total fetuses with thorax anomalies & 1 & 3 & 3 & 7 & 8 \\
\hline -Heart hypertrophy ${ }^{a}$ & 0 & $37.50^{b}$ & $23.07^{b}$ & $50.00^{\mathrm{bc}}$ & $37.50^{\mathrm{bd}}$ \\
\hline -Lung hypoplasia ${ }^{a}$ & 0 & $25.00^{\mathrm{b}}$ & $15.38^{\mathrm{b}}$ & $87.50^{\mathrm{bc}}$ & $50.00^{\text {bd }}$ \\
\hline -Intrathoracic hemorrhages ${ }^{a}$ & 1.56 & $12.25^{\mathrm{b}}$ & $7.69^{\mathrm{b}}$ & $62.50^{\mathrm{bc}}$ & $43.75^{\mathrm{bd}}$ \\
\hline Total fetuses with pelvic anomalies & 2 & 3 & 2 & 6 & 7 \\
\hline -Dilated renal pelvis ${ }^{a}$ & 3.12 & $37.50^{\mathrm{b}}$ & $15.38^{b}$ & $75.00^{\mathrm{bc}}$ & $43.75^{\mathrm{bd}}$ \\
\hline -Hydroureter ${ }^{a}$ & 0 & $12.25^{\mathrm{b}}$ & $7.69^{b}$ & $25.00^{\mathrm{bc}}$ & $12.50^{\mathrm{bd}}$ \\
\hline
\end{tabular}

Values represent percentage of viscerally deformed fetuses in relation to total number of fetuses examined.

bSignificant difference between control and Pestban-treated groups by Chi-Square test.

'Significant difference between Pestban-treated groups at $7.45 \mathrm{mg} / \mathrm{kg}$ bwt by Chi-Square test.

dSignificant difference between Pestban-treated groups at $3.72 \mathrm{mg} / \mathrm{kg}$ bwt by Chi-Square test. 
obtained at $20^{\text {th }}$ day of gestation and after weaning revealed significant increase in the percentage of stunted growth (Fig. 8), exencephaly, generalized edema, and micrognathia. The incidence of these fetal anomalies was more pronounced in the fetuses of treated female group than in the fetuses of treated male group at the two dose levels (Table 4).

Pestban significantly increased the incidence of visceral anomalies in the fetuses of both treated groups compared with control fetuses (Table 5). These anomalies were in the form of dilated brain ventricles (hydrocephaly) (Fig. 9), dilated nares, olfactory bulb and cerebral hemisphere hypoplasia, micro-and anophthalmia (Fig. 10), intrathoracic hemorrhage, heart and lung hypoplasia (Fig. 11), hydroureter, renal hypoplasia, and dilated renal pelvis (Fig. 12). The incidence of these visceral anomalies was greater in the fetuses of treated female

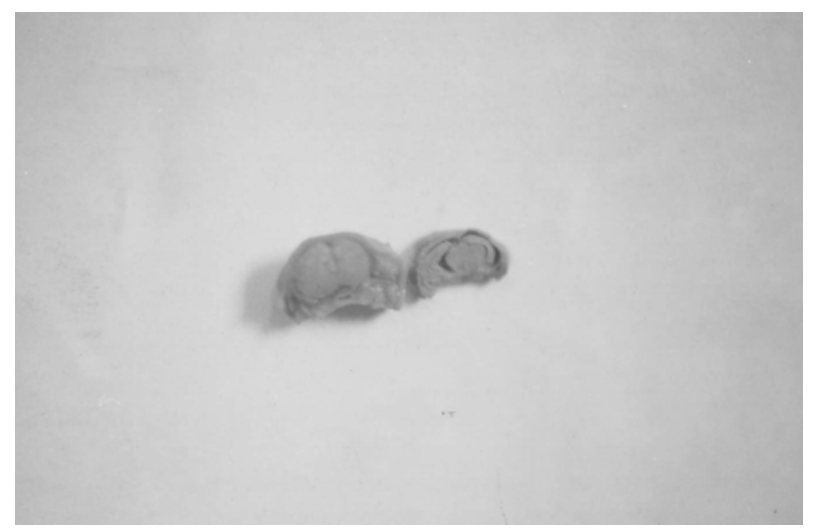

Fig. 9. A transverse section in the head of a rat fetus obtained from a dam exposed to Pestban at $7.45 \mathrm{mg} / \mathrm{kg}$ bwt orally and impregnated with untreated males showing dilated brain lateral ventricles (right) and a control one (left).

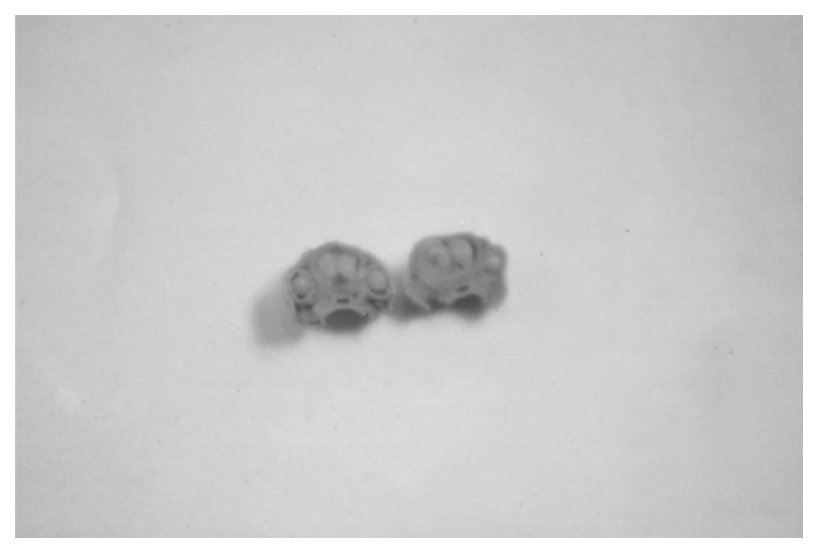

Fig. 10. A transverse section in the head of a rat fetus obtained from an untreated dam impregnated with males exposed to Pestban at $3.72 \mathrm{mg} / \mathrm{kg}$ bwt orally for 60 days daily showing anophthalmia (right) and a control one (left).

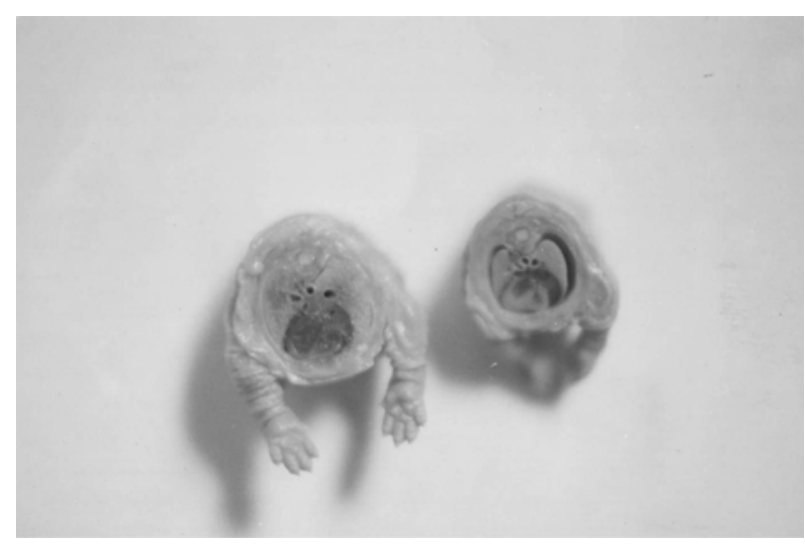

Fig. 11. A transverse section in the chest of a rat fetus obtained from a dam exposed to Pestban at $7.45 \mathrm{mg} / \mathrm{kg}$ bwt orally and impregnated with untreated males showing intrathoracic hemorrhages; lung and heart hypoplasia (right) and a control one (left).

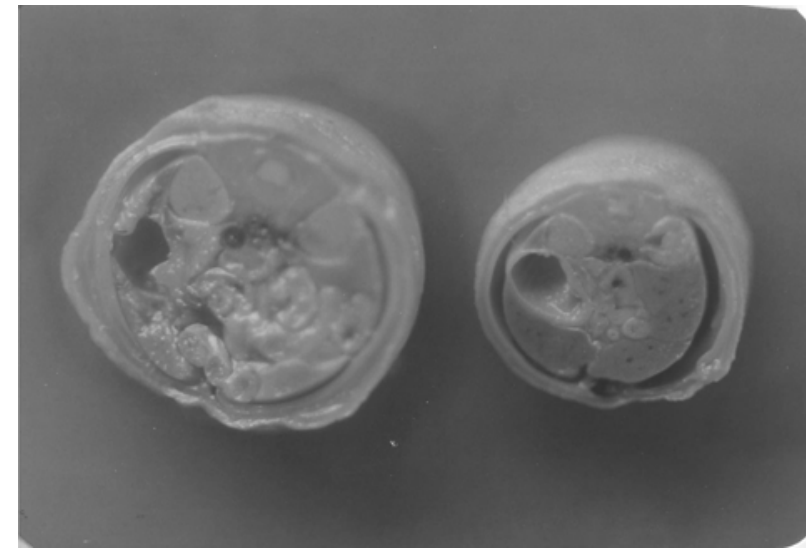

Fig. 12. A transverse section near the pelvic region in a weaned rat fetus obtained from an untreated dam impregnated with males exposed to Pestban at $7.45 \mathrm{mg} / \mathrm{kg}$ bwt orally for 60 days daily showing dilated renal pelvis (right) and a control one (left).

group compared with fetuses of treated male group especially at the high dose of this insecticide.

The incidence of skeletal anomalies in the fetuses of both treated groups was significantly increased compared with the control fetuses (Table 6). The recorded skeletal anomalies were in the form of wide separation of parietal bones, incomplete ossification of parietal and lor interparietal bones (Fig. 13), incomplete ossification of sternebrae, reduced sternbrae number (Fig. 14), wavy and extra ribs, absence of carpal and metacarpal, tarsal and metatarsal bones, absence of caudal bones and phalanges (Fig. 13). The incidence of these skeletal anomalies was more pronounced in fetuses of treated female group than in the fetuses of treated male 
Table 6. Incidences of skeletal anomalies in the fetuses obtained from Pestban-exposed male and female rat groups

\begin{tabular}{|c|c|c|c|c|c|}
\hline \multirow{2}{*}{$\begin{array}{l}\text { Groups } \\
\text { Parameters }\end{array}$} & \multirow{2}{*}{$\begin{array}{l}\text { Fetuses of } \\
\text { control group }\end{array}$} & \multicolumn{2}{|c|}{ Fetuses of treated male group } & \multicolumn{2}{|c|}{ Fetuses of treated female groups } \\
\hline & & At $7.45 \mathrm{mg} / \mathrm{kg}$ & At $3.72 \mathrm{mg} / \mathrm{kg}$ & At $7.45 \mathrm{mg} / \mathrm{kg}$ & At $3.72 \mathrm{mg} / \mathrm{kg}$ \\
\hline Total fetuses examined & 127 & 15 & 26 & 14 & 31 \\
\hline Total fetuses with skeletal anomalies & 2 & 6 & 4 & 13 & 18 \\
\hline Total fetuses with skull anomalies & 0 & 4 & 2 & 11 & 8 \\
\hline - Wide separation of parietal bones ${ }^{a}$ & 0 & $13.33^{\mathrm{b}}$ & 0 & $50.00^{b, c}$ & $19.35^{b, d}$ \\
\hline - Incomplete ossification of parietal bones ${ }^{a}$ & 0 & $20.00^{b}$ & $3.85^{\mathrm{a}}$ & $78.75^{\mathrm{b}, \mathrm{c}}$ & $25.81^{b, d}$ \\
\hline - Incomplete ossification of interparietal bones ${ }^{a}$ & 0 & $26.66^{b}$ & $7.69^{\mathrm{a}}$ & $64.28^{\mathrm{b}, \mathrm{c}}$ & $22.58^{b, d}$ \\
\hline Total fetuses with sternebrae anomalies & 1 & 5 & 3 & 10 & 10 \\
\hline - Incomplete ossification of sternebrae ${ }^{a}$ & 0 & $13.33^{\mathrm{b}}$ & $11.54^{\mathrm{a}}$ & $64.28^{\mathrm{bc}}$ & $22.58^{b, d}$ \\
\hline - Reduced sternebrae number ${ }^{a}$ & 0.79 & $33.33^{b}$ & $11.54^{\mathrm{a}}$ & $71.43^{b, c}$ & $32.26^{b, d}$ \\
\hline - Deformed ribs ${ }^{a}$ & 0 & $26.66^{\mathrm{b}}$ & $7.69^{\mathrm{a}}$ & $50.00^{\mathrm{b}, \mathrm{c}}$ & $25.81^{b, d}$ \\
\hline - Extra ribs ${ }^{a}$ & 0 & $26.00^{\mathrm{b}}$ & $3.85^{\mathrm{a}}$ & $35.71^{\mathrm{b}, \mathrm{c}}$ & $19.35^{b, d}$ \\
\hline Total fetuses with limb anomalies & 2 & 6 & 4 & 12 & 14 \\
\hline - Absence of carpal and/or metacarpal bones ${ }^{a}$ & 0 & $40.00^{b}$ & $15.38^{a}$ & $78.75^{\mathrm{b}, \mathrm{c}}$ & $41.94^{b, d}$ \\
\hline - Absence of tarsal and/or metatarsal bones ${ }^{a}$ & 0 & $33.33^{b}$ & $11.54^{\mathrm{a}}$ & $71.43^{b, c}$ & $38.71^{b, d}$ \\
\hline - Absence of phalanges ${ }^{a}$ & 1.57 & $20.00^{\mathrm{b}}$ & $7.69^{a}$ & $85.71^{\mathrm{b}, \mathrm{c}}$ & $45.61^{b, d}$ \\
\hline - Absence of caudal bones ${ }^{a}$ & 0 & $26.66^{\mathrm{b}}$ & $7.69^{a}$ & $50.00^{\mathrm{b}, \mathrm{c}}$ & $29.03^{b, d}$ \\
\hline
\end{tabular}

${ }^{a}$ Values represent percentage of skeletally deformed fetuses in relation to total number of fetuses examined.

bSignificant difference between control and Pestban-treated groups by Chi-Square test.

'Significant difference between Pestban-treated groups at $7.45 \mathrm{mg} / \mathrm{kg}$ bwt by Chi-Square test.

${ }^{d}$ Significant difference between Pestban-treated groups at $3.72 \mathrm{mg} / \mathrm{kg}$ bwt by Chi-Square test.

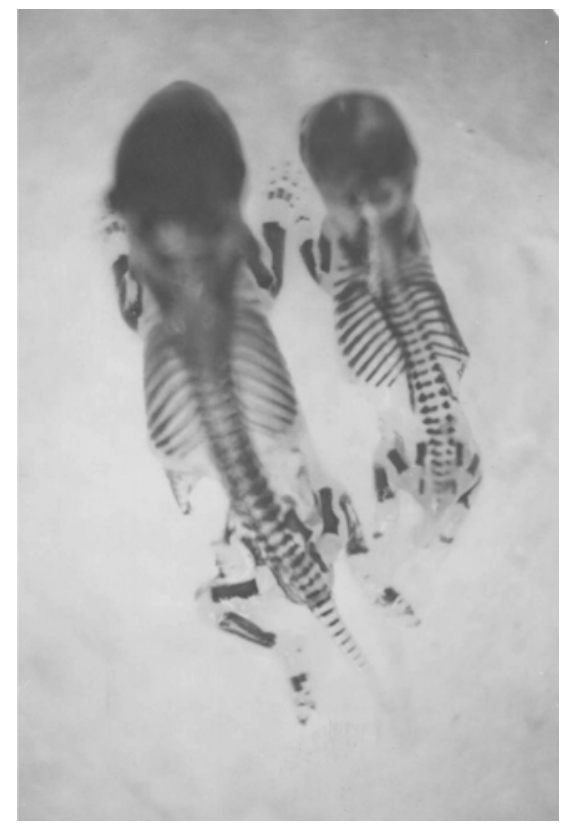

Fig. 13. A rat fetus obtained from an untreated dam impregnated with males exposed to Pestban at $7.45 \mathrm{mg} / \mathrm{kg}$ bwt orally for 60 days daily showing incomplete ossification of skull bones and phalanges as well as absence of sacral and coccygeal vertebrae.

group and occurred in a dose-related manner.

\section{DISCUSSION}

The aim of the present study was to monitor the

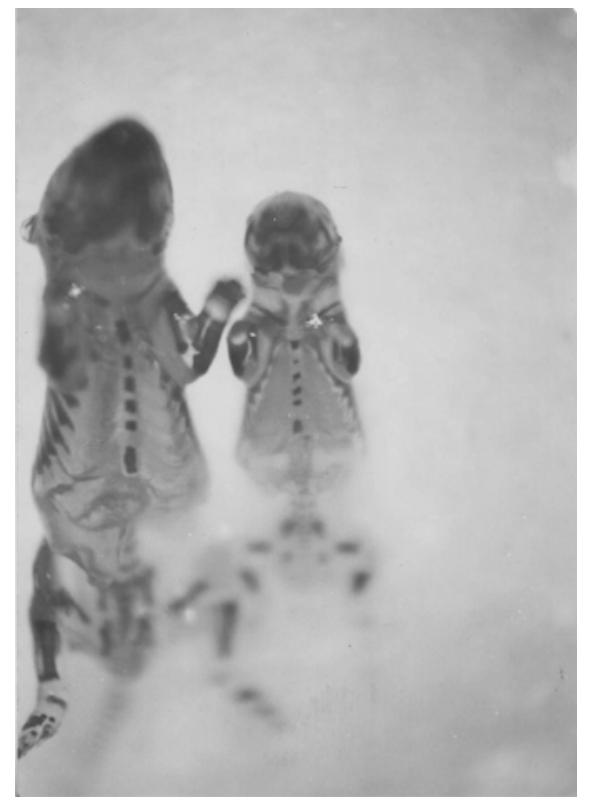

Fig. 14. A rat fetus obtained from a dam exposed to Pestban at $3.72 \mathrm{mg} / \mathrm{kg}$ but orally and impregnated with untreated males showing incomplete ossification of sternbrae (right) and a control fetus (left).

adverse effects of Pestban on fertility and reproduction of both male and female rats. Generally there was no mortality or clinical signs of toxicity in any of the exposed male or female groups at the lowest dose $(3.72 \mathrm{mg} / \mathrm{kg})$. However, signs of cholinergic toxicity including tremors and salivation were noted in $60 \%$ of 
treated males and in $70 \%$ of treated females at the highest dose $(7.45 \mathrm{mg} / \mathrm{kg})$. This was associated by the significantly inhibited brain AChE activity in the highest Pestban-treated groups compared to control and lowest Pestban-treated groups.

The obtained results showed that exposure of male and female rats to Pestban had adverse effects on their reproductive performance and fertility. Similarly, exposure of rabbits to CPF orally at 0.1 and $0.05 \mathrm{mg} / \mathrm{kg}$ daily for 70 and 30 days, respectively reduced male and female fertility with severe ovarian and testicular histopathological alterations (Bansal et al., 1994). The observed inhibition of parental and neonatal AChE activities, reproductive and neonatal adverse effects following Pestban exposure agree with the results of Astroff et al. (1998) and Farag et al. $(2003,2006)$ in rats following exposure to either tribufos, oxydemeton-methyl, fenamiphos, coumaphos, trichlorfon, CPF or dimethoate as OPI. Pestban-induced AChE suppression may be due to adverse effects on neuronal activity which normally regulates critical genes such as the neurotrophins nerve growth factor (NGF) and brain-derived neurotrophic factor (BDNF) (Betancourt et al., 2007).

Testicular lesions due to organophosphates exposure were also recorded by Carleton et al. (1987); Somkuti et al. (1991) and Piramanayagam et al. (1996) in rats, Wenda-Rozewicka (1984) and Chapin et al. (1988) in mice, and Bansal et al. (1994) in rabbits. In addition, the recorded Pestban-induced adverse effects on testis, accessory sex glands, male reproductive performance, and fertility are in coincidence with the results of Ray et al. (1991, 1992); Cho and Park (1994) and Piramanayagam et al. (1996) in exposed adult rats to quinalphos; dimethyl methylphosphonate (DMMP) or trimethylphosphate (TMP), and malathion, respectively. Moreover, Debnath and Mandal (2000); Kamijima et al. (2004) and Okamura et al. (2005) confirmed the male reproductive toxicity of OPI in animals and humans with the induction of testicular lesions. Narayana et al. (2006) mentioned that neonatal \{on postnatal day (PND) 3 to PND $28\}$ oral methyl parathion exposure of rat affected the growth and functions of the male reproductive system in the adult life.

AChE and butyrylcholinesterase (BuChE) activities have been identified in mouse and rat Sertoli cells and spermatozoa (Chakraborty and Nelson, 1976). The observed antifertility effect of Pestban could be attributed to its $A C h E$ inhibiting activity and the consequent suppression of sperm motility which is dependent on presence of acetylcholine (Harbison et al., 1976; AbouDonia, 1985). Studies have shown that antiandrogenic activity (Tomura et al., 2001; Kitamura et al., 2003;
Kojima et al., 2004); altered androgen metabolism (Hodgson and Rose, 2006); pathological changes in the testes (Chapin et al., 1988); mutagenic potential on spermatogonial cells (El Nahas et al., 1989) and suppressive effect on the functional activity of accessory sex glands (Ray et al., 1991) may be responsible for decreased reproductive performance in animals exposed to organophosphates. Moreover, Sanchez-Pena et al. (2004) suggested that OPI exposure alters sperm chromatin condensation, which could be reflected in an increased number of cells with greater susceptibility to DNA denaturation and may contribute to adverse reproductive outcomes. Therefore, the declined mating and fertility indices of the treated males following Pestban exposure may be due to its adverse effect on AChE; spermatogonial DNA, androgen metabolism; accessory sex glands and/or testicular function. This was confirmed by the recorded adverse effects on the weight and histological structures of the male sex organs.

Administration of $3.72 \mathrm{mg} / \mathrm{kg}$ per day Pestban to adult female rats by gavage did not produce maternal toxicity but induced embryo-/feto-toxicity and teratogenicity. These results are consistent with the previous studies that addressed the potential embryotoxicity and teratogenicity of anticholinesterase compounds (Lozano et al., 1989; Soni and Bhatngar, 1989; Weber, 1990; Srivastava et al., 1992; Chanda et al., 1995; Srivastava and Raizada, 1996; Dam et al., 1998; Farag et al., 2003; Akhtar et al., 2006). Developmental toxicity was observed in the two treated groups at the two dose levels with suppressed placental, maternal, and fetal brain cholinesterase activity especially in the treated female group at the high dose level. The recorded AChE suppressive properties of Pestban probably contributed to its embryolethality and developmental toxicity (Lassiter et al., 1998; Slotkin, 1999). In addition, the inhibition of fetal brain cholinesterase may be deleterious to the coordinated development of the brain given the postulated novel role for the cholinesterases in nervous system development (Lassiter et al., 1998). Chlorpyrifos disrupted the maturation of sea urchin embryos during the specific period during which development is regulated by neurotrophic factors (Buznikov et al., 2001). Studies suggested that CPF may directly influence brain cell replication and differentiation (Dam et al., 1998; Crumpton et al., 2000). Chlorpyrifos has immediate direct inhibitory actions on DNA synthesis and hence on neural cell replication, with preferential targeting of gliotypic cells (Lassiter et al., 1998). Therefore, chlorpyrifos may induce damage by both noncholinergic and cholinergic mechanisms extending from early stages of neural cell replication through late stages of axonogenesis and ter- 
minal differentiation (Slotkin, 1999).

The number of implantation sites and the number of viable fetuses were significantly reduced in pregnant females of both treated groups at the two dose levels. However, the number of resorptions, dead fetuses and pre-and postimplantation losses were significantly increased. Organophosphorus compounds have been reported to induce early and late embryonic deaths (Chanda et al., 1995; Srivastava and Raizada, 1996; Dam et al., 1998; Farag et al., 2003; Mahadevaswami and Kaliwal, 2003). The Pestban-induced implantation delay and nidation could be attributed to an imbalance in the estrogen-progesterone ratio, which is essential for implantation (Mahadevaswami and Kaliwal, 2003). Alternatively, Pestban treatment could result in blastotoxicity and/or have an impact on the hypothalamic-pituitary axis.

The incidence of resorptions was significantly increased in treated female group impregnated with untreated males compared with untreated female group impregnated with treated males. The observed increase in embryonal resorptions in female rats exposed to Pestban most probably resulted from modification of the uterine lining function and/or transplacental Pestban passage with subsequent AChE inhibition (Srivastava et al., 1992; Slotkin, 1999; Farag et al., 2003; Akhtar et al., 2006).

During the lactation period, the fetal body weight, survival and viability indices, and the behavioral responses such as memory response and brain AChE were significantly decreased in the treated female group impregnated with untreated males compared with untreated female group impregnated with treated males. It has been reported that lactation exposure of suckling mice to malathion through maternal milk caused a high inhibitory effect of the brain AChE activity in the offspring summing to the fact that OPI are excreted in milk (Silva et al., 2006).

Similar effects to those of Pestban on the pup viability and survival were observed by Carleton et al. (1987) after daily oral treatment of both male (for 56 days) and female (for 14 days prior to mating and throughout the mating period, gestation and lactation) rats with tricresyl phosphate (TCP). Furthermore, it has been reported that malathion exposure reduced the size of rat litters and decreased the survival rate of the young (Harte et al., 1991). The fetal growth retardation and neonatal deaths (decreased survival and viability indices) in rats exposed to organophosphates could be a consequence of alteration of the milk lipase activity with a diminished secretory function in the mammary gland leading to interference with nursing of the offsprings (Fish, 1966). Moreover, Pestban is a potent inhibitor of DNA and pro- tein synthesis that could affect several metabolic processes (Nehez and Desi, 1996; Blasiak et al., 1999; Eskenazi et al., 1999). These effects might be responsible for Pestban-induced fetal growth retardation and developmental toxicity.

The observed behavioral disturbances were similar to the results of Eskenazi et al. (1999). Richardson and Chambers $(2004,2005)$ found that gestational and postnatal oral exposure of rat to $1.5-7 \mathrm{mg} / \mathrm{kg} / \mathrm{day} C P F$ resulted in long-term alterations of presynaptic cholinergic neurochemistry in developing pups. These behavioral disturbances could be attributed to the effects of Pestban on the central nervous system, most importantly, alteration in the content of AChE, which participate in the morphological process and the maturation of central nervous system (Lassiter et al., 1998; Slotkin, 1999), down-regulation of muscarinic receptors and decreased brain DNA synthesis (Eskenazi et al., 1999). Additionally, it might be due to the generation of free radical in the developing rat brain (Gupta et al., 1998).

The incidences of the recorded gross, visceral, and skeletal anomalies were significantly increased in the fetuses obtained from treated female group compared with the fetuses of treated male group with significantly increased percentages at the high dose level. This could be attributed to transplacental transfer of Pestban to the fetuses from exposed pregnant females during the organogenesis period (Srivastava et al., 1992; Farag et al., 2003; Akhtar et al., 2006). The organogenesis period considered the most sensitive period of fetal developmental abnormalities (Leone, 1977). The placenta may be directly involved in many instances of early spontaneous abortions, fetal death, and intrauterine growth retardation (Faulk, 1981). The associations between ChE levels in placenta and parameters of fetal growth and length of gestation are in agreement with the results of Eskenazi et al. (2004). Lower levels of ChE in placenta were associated with significantly shorter length of gestation. Decreasing the levels of placental ChE were also associated with increased incidences of dystocia, preterm labour (shortened birth date) and low birth weight. Moreover, placental ChE levels were also associated with most of the other fetal parameters and birth outcome. Cholinergic nerves play a significant role in the control of the uterine musculature and myometrium. Acetylcholine stimulates contraction of the uterus and dilates its arterial supply (Papka et al., 1999). Thus, an inhibition of acetyl ChE could produce an accumulation of acetylcholine in the neuronal junctions and hence the over-stimulation of cholinergic fibers resulting in premature initiation of labour. In addition, premature delivery may be the cause of 
decreased survival and viability of the fetuses during lactation.

Many trends in teratogenicity research have focused on the possibility that the disruption in morphogenesis may be related to alkylation of nucleic acids by organophosphates (Bedford and Robinson, 1972). It has been postulated that alkylation of NAD coenzymes by organophosphates may be a major factor in the induction of teratogenesis (Schoental, 1977). Other investigators have found altered levels of RNA, glycogen, sulfated mucopolysaccharides and calcium by organophosphates in the developing tibiotarsus of chick embryo (Ho and Gibson, 1972).

In conclusion, the present study indicates that oral exposure to Pestban by male and female rats during the different phases of reproduction affect male and female fertility with teratogenic and postnatal effects on the growing fetuses. The fetal developmental effects were greater in treated females compared with untreated females impregnated with treated males and occurred in a dose related manner.

\section{ACKNOWLEDGMENTS}

Grateful thanks offered to Dr. A. Bakeer, Prof. of Pathology, Faculty of Veterinary Medicine, Cairo University for his help in the histopathological examination.

\section{REFERENCES}

Abou-Donia, M.B. (1985). Biochemical Toxicity of Organophosphorus Compounds. In Neurotoxicology (K. Blum and L. Manzo, Eds.), Dekker, New York.

Akhtar, N., Srivastava, M.K. and Raizada, R.B. (2006). Transplacental disposition and teratogenic effects of chlorpyrifos in rats. J. Toxicol. Sci., 31, 521-527.

Andersen, H.R., Vinggaard, A.M., Rasmussen, T.H., Gjermandsen, I.M. and Bonefeld-Jorgensen, E.C. (2002). Effects of currently used pesticides in assays for estrogenicity, androgenicity, and aromatase activity in vitro. Toxicol. Appl. Pharmacol., 179, 1-12.

Astroff, A.B., Freshwater, K.J. and Eigenberg, D.A. (1998). Comparative organophosphate-induced effects observed in adult and neonatal Sprague-Dawley rats during the conduct of multigeneration toxicity studies. Reprod. Toxicol., 12, 619-645.

Bansal, N., Pawar, H.S. and Roy, K.S. (1994). Pathology of urogenital organs in chlorpyrifos toxicity in rabbits. Indian J. Vet. Pathol., 18, 34-37.

Bedford, C.T. and Robinson, J. (1972). The alkylating properties of organophosphates. Xenobiotica, 2, 307-337.

Betancourt, A.M., Filipov, N.M. and Carr, R.L. (2007). Alteration of neurotrophins in the hippocampus and cerebral cortex of young rats exposed to chlorpyrifos and methyl parathion. Toxicol. Sci., 100, 445-455.
Blasiak, J., Jaloszynski, P., Trzeciak, A. and Szyfter, K. (1999). In vitro studies on the genotoxicity of the organophosphorus insecticide malathion and its two analogues. Mutat Res., 445, 275-283.

Buznikov, G.A., Nikitina, L.A., Bezuglov, V.V., Lauder, M., Padilla, S. and Slotkin, T.A. (2001). An invertebrate model of the developmental neurotoxicity of insecticides: effects of chlorpyrifos and dieldrin in sea urchin embryos and larvae. Environ. Health Perspect., 109, 651-661.

Carleton, B.D., Hasaran, A.H., Mezza, L.E. and Smith, M.K. (1987). Examination of the reproductive effects of tricresyl phosphate administered to Long Evans rats. Toxicology, 46, 321-328.

Chakraborty, J. and Nelson, L. (1976). Comparative study of cholinesterase distribution in the spermatozoa of some mammalian species. Biol. Reprod., 15, 579-585.

Chanda, S.M., Harp, P., Liu, J. and Pope, C.N. (1995). Comparative developmental and maternal neurotoxicity following acute gestational exposure to chlorpyrifos in rats. $\mathrm{J}$. Toxicol. Environ. Health, 44, 189-202.

Chapin, R.E., George, J.D. and Lamb, J.C. 4th (1988). Reproductive toxicity of tricresyl phosphate in a continuous breeding protocol in Swiss (CD-1) mice. Fundam. Appl. Toxicol., 10, 344-354.

Cho, N.H. and Park, C. (1994). Effects of dimethyl methylphosphonate (DMMP) and trimethylphosphate (TMP) on spermatogenesis of rat testis. Yonsei Med. J., 35, 198208.

Clemens, G.R., Hartnagel, R.E., Bare, J.J. and Thyssen, J.H. (1990). Teratological, neurochemical, and postnatal neurobehavioral assessment of METASYSTOX-R, an organophosphate pesticide in the rat. Fundam. Appl. Toxicol., 14, 131-143.

Crumpton, T.L., Seidler, F.J. and Slotkin, T.A. (2000). Developmental neurotoxicity of chlorpyrifos in vivo and in vitro: effects on nuclear transcription factors involved in cell replication and differentiation. Brain Res., 857, 87-98.

Dabrowski, S., Hanke, W., Polanska, K., Makowiec-Dabrowska, T. and Sobala, W. (2003). Pesticide exposure and birthweight: an epidemiological study in Central Poland. Int. J. Occup. Med. Environ. Health, 16, 31-39.

Dam, K., Seidler, F.J. and Slotkin, T.A. (1998). Developmental neurotoxicity of chlorpyrifos: delayed targeting of DNA synthesis after repeated administration. Brain. Res. Dev. Brain. Res., 108, 39-45.

Debnath, D. and Mandal, T.K. (2000). Study of quinalphos (an environmental oestrogenic insecticide) formulation (Ekalux 25 E.C.)-induced damage of the testicular tissues and antioxidant defence systems in Sprague-Dawley albino rats. J. Appl. Toxicol., 20, 197-204.

El Nahas, S.M., de Hondt, H.A. and Abdou, H.E. (1989). Chromosome aberrations in spermatogonia and sperm abnormalities in Curacron-treated mice. Mutat. Res., 222, 409-414.

Eskenazi, B., Bradman, A. and Castorina, R. (1999). Exposures of children to organophosphate pesticides and their potential adverse health effects. Environ. Health Perspect., 107, 409-419.

Eskenazi, B., Harley, K., Bradman, A., Weltzien, E., Jewell, 
N.P., Barr, D.B., Furlong, C.E. and Holland, N.T. (2004). Association of in utero organophosphate pesticide exposure and fetal growth and length of gestation in an agricultural population. Environ. Health Perspect., 112, 11161124.

Farag, A.T., El Okazy, A.M. and El-Aswed, A.F. (2003). Developmental toxicity study of chlorpyrifos in rats. Reprod. Toxicol., 17, 203-208.

Farag, A.T., Karkour, T.A. and El Okazy, A. (2006). Developmental toxicity of orally administered technical dimethoate in rats. Birth Defects Res. B Dev. Reprod. Toxicol., 77, 40-46.

Faulk, W.P. (1981). Trophoblast and extraembryonic membranes in the immunobiology of human pregnancy. In: (R.K. Miller and H.A. Thiede, Eds.), Placenta: Receptors, Pathology and Toxicology; WB Sanders, London, pp. 322.

Fish, S.A. (1966). Organophosphorus cholinesterase inhibitor and fetal development. Amer. J. Obest. Gynaecol., 96, $1148-1154$.

Fox, R.P. and Laird, C.W. (1970). Sexual cycles. In: Reproduction and breeding techniques for laboratory animals. (E.S.E. Hafez, Ed.), Lea and Febiger, Philadelphia, Penn, pp. 107-122

Garey, J. and Wolff, M.S. (1998). Estrogenic and antiprogestagenic activities of pyrethroid insecticides. Biochem. Biophys. Res. Commun., 251, 855-859.

Gibson, J.E., Peterson, R.K. and Shurdut, B.A. (1998). Human exposure and risk from indoor use of chlorpyrifos. Environ. Health Perspect., 106, 303-306.

Gupta, A., Gupta, A. and Shukla, G.S. (1998). Effects of neonatal quinalphos exposure and subsequent withdrawal on free radical generation and antioxidative defenses in developing rat brain. J. Appl. Toxicol., 18, 71-77.

Harbison, R.D., Dwivedi, C. and Evans, M.A. (1976). A proposed mechanism for trimethylphosphate-induced sterility. Appl. Pharmacol., 35, 481-490.

Harte, J., Holdren, C., Schneider, R. and Shirley, C. (1991). Toxics $A$ to $Z$ : $A$ guide to every day pollution hazards. University of California press. Barkeley, Loss angeles, Oxford.

Hass, P.J., Buck, W.P., Hixon, J.E., Shanks, R.D., Wagner, W.C., Weston, P.G. and Whitmore, H.L. (1983). Effect of chlorpyrifos on Holestein steers and testosterone treated bulls. Am. J. Vet. Res., 44, 879-881.

Hodgson, E. abd Rose, R.L. (2006). Organophosphorus chemicals: potent inhibitors of the human metabolism of steroid hormones and xenobiotics.1 Drug Metab. Rev., 38, 149-162.

Ho, M. and Gibson, M.A. (1972). A histochemical study of the developing tibiotarsus in malathion treated chick embryos. Can. J. Zool., 5, 1293-1298.

Institoris, L., Siroki, O. and Desi, I. (1995). Immunotoxicity study of repeated small doses of dimethoate and methylparathion administered to rats over three generations. Hum. Exp. Toxicol., 14, 879-883.

Johnson, C.D. and Russell, R.L. (1975). A rapid, simple radiometric assay for cholinesterase, suitable for multiple determinations. Anal. Biochem., 64, 229-238.
Kamijima, M., Hibi, H., Gotoh, M., Taki, K., Saito, I., Wang, H., Itohara, S., Yamada, T., Ichihara, G., Shibata, E., Nakajima, T. and Takeuchi, Y. (2004). A survey of semen indices in insecticide sprayers. J. Occup. Health, 46, 109118

Kanojia, R.K., Junaid, M. and Murthy, R.C. (1996). Chromium induced teratogenicity in female rat. Toxicol. Lett., 89, 207-213

Karalliedde, L., Feldman, S., Henry, J. and Marrs, T. (2001). Organophosphates and Health. River Edge, $\mathrm{NJ}$ : World Scientific Publishing.

Kitamura, S., Suzuki, T., Ohta, S. and Fujimoto, N. (2003). Antiandrogenic activity and metabolism of the organophosphorus pesticide fenthion and related compounds. Environ. Health Perspect., 111, 503-508.

Kojima, H., Katsura, E., Takeuchi, S., Niiyama, K. and Kobayashiv, K. (2004). Screening for estrogen and androgen receptor activities in 200 pesticides by in vitro reporter gene assays using Chinese hamster ovary cells. Environ. Health Perspect., 112, 524-531.

Kristensen, P., Irgens, L.M., Andersen, A., Bye, A.S. and Sundheim, L. (1997). Gestational age, birth weight, and perinatal death among births to Norwegian farmers, 1967 1991. Am. J. Epidemiol., 146, 329-338.

Lassiter, T.L., Padilla, S., Mortensen, S.R., Chanda, S.M., Moser, V.C. and Barone, S. Jr. (1998). Gestational exposure to chlorpyrifos: apparent protection of the fetus? Toxicol. Appl. Pharmacol., 152, 56-65.

Layer, P.G. and Willobold, E. (1995). Novel functions of cholinesterases in development, physiology, and disease. Prog. Histochem. Cytochem., 29, 1-94.

Leone, V.G. (1977). Comparative aspects of developmental stages in mammals used for teratogenic tests. In: Methods in Prenatal Toxicology, Neubert D, Merker HJ, Kwasigroch (Eds.). George Thieme Publishers Stuttgart, pp. 1424.

Lowry, O.H., Rosebrough, N.J., Farr, A.L. and Randall, R.J. (1951). Protein measurement with the folin phenol reagent. J. Biol. Chem., 193, 265-275.

Lozano, A.M.A., Manzanilla, C.M., Alvarez, L.R. and Reyes, R.E. (1989). Mutagenic and teratogenic effects of diazinon. Revista Intermational Decontamination Ambiental, 5, 49-249.

Mahadevaswami, M.P. and Kaliwal, B.B. (2003). Evaluation of dimethoate-induced implantation delay and nidation by progesterone in albino mice. J. Basic Clin. Physiol. Pharmacol., 14, 43-54.

Manson, J.M. and Kang, Y.J. (1989). Test methods for assessment of female reproductive and developmental toxicology. In: Principles and Methods of Toxicology, Hayes AW. Raven Press; New York, pp. 311-361.

Nafstad, I., Berge, G., Sannes, E. and Lyngest, A. (1983). Teratogenic effects of the organophosphorus compound fenchlorphos in rabbits. Acta Vet. Scand., 24, 295-304.

Narayana, K., Prashanthi, N., Nayanatara, A., Kumar, H.H., Abhilash, K. and Bairy, K.L. (2006). Neonatal methyl parathion exposure affects the growth and functions of the male reproductive system in the adult rat. Folia Morphol. (Warsz), 65, 26-33. 
Nehez, M. and Desi, I. (1996). The effect of dimethoate on bone marrow cell chromosomes of rats in subchronic four-generation experiments. Ecotoxicol. Environ. Saf., 33, 103-109.

Norusis, M. (1994). Statistical package for social sciences, version 6. USA: SPSS Incorporation.

Okamura, A., Kamijima, M., Shibata, E., Ohtani, K., Takagi, K., Ueyama, J., Watanabe, Y., Omura, M., Wang, H., Ichihara, G., Kondo, T. and Nakajima, T. (2005). A comprehensive evaluation of the testicular toxicity of dichlorvos in Wistar rats. Toxicology, 213, 129-137.

Papka, R.E., Traurig, H.H., Schemann, M., Collins, J., Copelin, T. and Wilson, K. (1999). Cholinergic neurons of the pelvic autonomic ganglia and uterus of the female rat: distribution of axons and presence of muscarinic receptors. Cell Tissue Res., 296, 293-305.

Piramanayagam, S., Manohar, B.M. and Sundararaj, A. (1996). Pathology of malathion toxicity in rats. Indian Vet. J., 73, 734-737.

Raines, K.W., Seidler, F.J. and Slotkin, T.A. (2001). Alterations in serotonin transporter expression in brain regions of rats exposed neonatally to chlorpyrifos. Brain Res. Dev. Brain Res., 130, 65-72.

Ray, A., Chatterjee, S., Ghosh, S., Kabir, S.N., Pakrashi, A. and Deb, C. (1991). Suppressive effect of quinalphos on the activity of accessory sex glands and plasma concentrations of gonadotrophins and testosterone in rats. Arch. Environ. Contam. Toxicol., 21, 383-387.

Ray, A., Chatterjee, S., Ghosh, S., Bhattacharya, K., Pakrashi, A. and Deb, C. (1992). Quinalphos-induced suppression of spermatogenesis, plasma gonadotrophins, testicular testosterone production, and secretion in adult rats. Environ. Res., 57, 181-189.

Richardson, J.R. and Chambers, J.E. (2004). Neurochemical effects of repeated gestational exposure to chlorpyrifos in developing rats. Toxicol. Sci., 77, 83-90.

Richardson, J.R. and Chambers, J.E. (2005). Effects of repeated oral postnatal exposure to chlorpyrifos on cholinergic neurochemistry in developing rats. Toxicol. Sci., 84, 352-359.

Sanchez-Pena, L.C., Reyes, B.E., Lopez-Carrillo, L., Recio, R., Moran-Martinez, J., Cebrian, M.E. and Quintanilla-Vega, B. (2004). Organophosphorous pesticide exposure alters sperm chromatin structure in Mexican agricultural workers. Toxicol. Appl. Pharmacol., 196, 108-113.

Schoental, R. (1977). Depletion of coenzymes at the site of rapidly growing tissues due to alkylation: The biochemical bases of teratogenic effects of alkylating agents, includ- ing organophosphorus and certain other compounds. Biochem. Soc. Trans., 5, 1016.

Silva, A.P., Meotti, F.C., Santos, A.R. and Farina, M. (2006). Lactational exposure to malathion inhibits brain acetylcholinesterase in mice. Neurotoxicology, 27, 1101- 1105.

Slotkin, T.A. (1999). Developmental cholinotoxicants: Nicotine and chlorpyrifos. Environ. Health Perspect., 107, 71-80.

Small, H., Michaelson, S. and Sberna, G. (1996). Non-classical actions of cholinesterases: role in cellular differentiation, tumorigenesis, and Alzheimer's disease. Neurochem. Int., 28, 453-483.

Somkuti, S.G., Lapadula, D.M., Chapin, R.E. and Abou-Donia, M.B. (1991). Light and electron microscopic evidence of tri-o-cresyl phosphate (TOCP) mediated testicular toxicity in Fischer 344 rats. Toxicol. Appl. Pharmacol., 107, 35-46.

Soni, I. and Bhatngar, P. (1989). Embryotoxic and teratogenic studies of phosphamidon in Swiss albino mice. Teratog. Carcinog. Mutagen., 9, 253-257.

Srivastava, M.K., Raizada, R.B. and Dikshith, T.S. (1992). Fetotoxic response of technical quinalphos in rats. Vet. Hum. Toxicol., 34, 131-133.

Srivastava, M.K. and Raizada, R.B. (1996). Development effect of technical dimethoate in rats: maternal and fetal toxicity evaluation. Indian J. Exp. Biol., 34, 329-333.

Tomura, A., Goto, K., Morinaga, H., Nomura, M., Okabe, T., Yanase, T., Takayanagi, R. and Nawata, H. (2001). The subnuclear three-dimensional image analysis of androgen receptor fused to green fluorescence protein. J. Biol. Chem., 276, 28395-28401.

Weber, M. (1990). The effect of dimethoate and vibration on fetal development in the rat. Anat. Anz., 170, 221-226.

Wenda-Rozewicka, L. (1984). Morphometric studies of male gonads from mice receiving insecticides (Metox-30; Sadafos30 and Foschhlor-50). Folia Biol. (Krakow), 32, 23-34.

Whyatt, R.M., Camann, D.E., Kinney, P.L., Reyes, A., Ramirez, J., Dietrich, J., Diaz, D., Holmes, D. and Perera, F.D. (2002). Residential pesticide use during pregnancy among a cohort of urban minority women. Environ. Health Perspect., 110, 507-514.

Willis, W.O., de Peyster, A., Molgaard, C.A., Walker, C. and MacKendrick, T. (1993). Pregnancy outcome among women exposed to pesticides through work or residence in an agricultural area. J. Occup. Med., 35, 943-949.

Wilson, J.C. (1973). Environmental and birth defects, Academic Press, New York; appendix 3, 227-232.

Worthing, C.R. and Walker, S.B. (1994). The pesticide mannual, 10th Ed., a world Compendium, British Crop Protection Council, pp. 200-201. 